\title{
Diversity and evolution of Amazonian birds: implications for conservation and biogeography
}

\author{
CAMILA C. RIBAS ${ }^{1}$ and ALEXANDRE ALEIXO ${ }^{2}$ \\ ${ }^{1}$ Coordenação de Biodiversidade, Instituto Nacional de Pesquisas da Amazônia, \\ Av. André Araújo, 2936, 69060-001 Manaus, AM, Brazil \\ ${ }^{2}$ Finnish Museum of Natural History, University of Helsinki, P.O. Box 17, 00014, Helsinki, Finland \\ Manuscript received on February 21, 2019; accepted for publication on May 12, 2019
}

\begin{abstract}
How to cite: RIBAS CC AND ALEIXO A. 2019. Diversity and evolution of Amazonian birds: implications for conservation and biogeography. An Acad Bras Cienc 91: e20190218. DOI 10.1590/0001-3765201920190218.

Abstract: Amazonia has been a focus of interest since the early days of biogeography as an intrinsically complex and extremely diverse region. This region comprises an intricate mosaic that includes diverse types of forest formations, flooded environments and open vegetation. Increased knowledge about the distribution of species in Amazonia has led to the recognition of complex biogeographic patterns. The confrontation of these biogeographic patterns with information on the geological and climatic history of the region has generated several hypotheses dedicated to explain the origin of the biological diversity. Genomic information, coupled with knowledge of Earth's history, especially the evolution of the Amazonian landscape, presents fascinating possibilities for understanding the mechanisms that govern the origin and maintenance of diversity patterns in one of the most diverse regions of the world. For this we will increasingly need more intense and coordinated interactions between researchers studying biotic diversification and the evolution of landscapes. From the interaction between these two fields of knowledge that are in full development, an increasingly detailed understanding of the historical mechanisms related to the origin of the species will surely arise.
\end{abstract}

Key words: Amazonia, biogeography, birds, conservation, diversification, rivers.

\section{INTRODUCTION}

Amazonia has been a focus of interest since the early days of biogeography as an intrinsically complex and extremely diverse region (Wallace 1852, Haffer 1969). This region comprises an intricate mosaic that includes diverse types of forest formations, flooded environments and open vegetation (CohnHaft et al. 2007) (Figure 1). Increased knowledge

E-mail: camilaribas@gmail.com

ORCid: http://orcid.org/0000-0002-9088-4828

alexandre.aleixo@helsinki.fi

ORCid : http://orcid.org/0000-0002-7816-9725 about the distribution of species in Amazonia has led to the recognition of complex biogeographic patterns (Antonnelli et al. 2010, Ribas et al. 2012, Smith et al. 2014, Naka and Brumfield 2018). The confrontation of these biogeographic patterns with information on the geological and climatic history of the region has generated several hypotheses dedicated to explain the origin of the biological diversity (reviews in Haffer 2008 and Leite and Rogers 2013).

Since the proposition of these hypotheses, much knowledge has been accumulated, both with respect to biogeographic patterns (inter and 

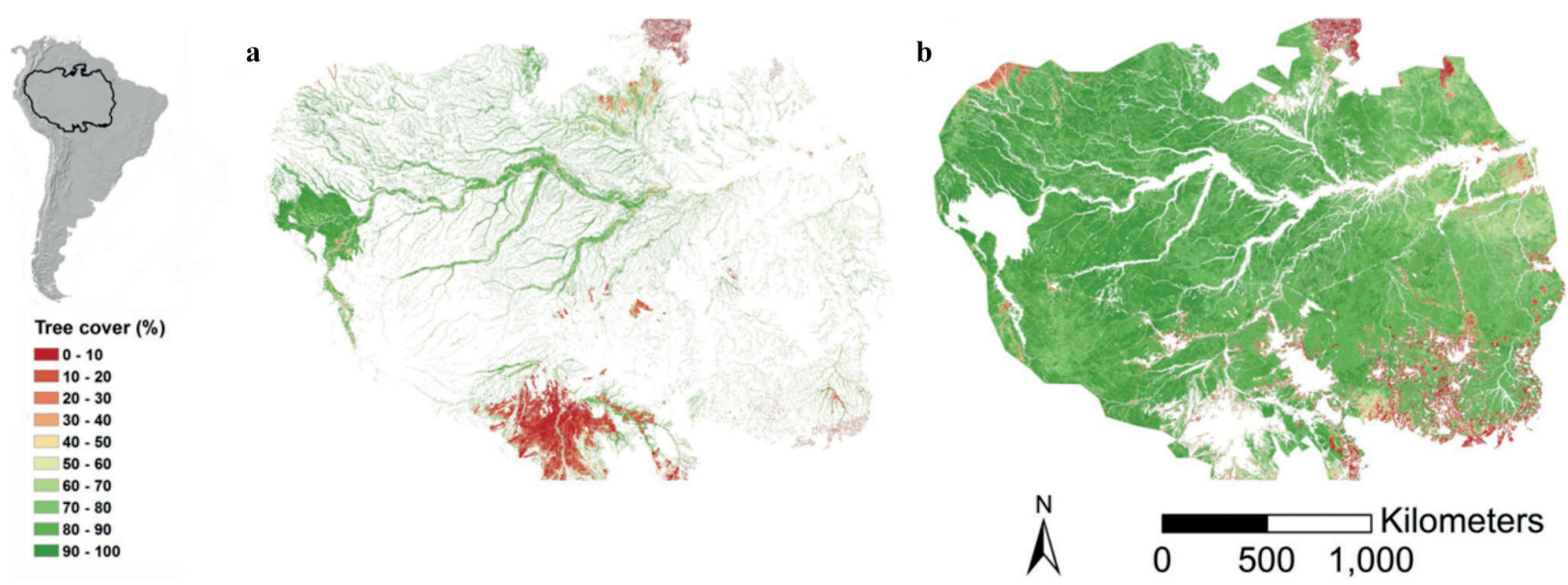

Figure 1 - Distribution of tree cover across the Amazon basin. (a) Floodplains and (b) uplands separated by the wetlands' mask (Hess et al. 2015). Figure from Flores et al. (2017).

intra-specific), and the evolution of Amazonian landscapes. In general, one can identify two main themes in Amazonian biogeography in which the accumulation of paleo-environmental knowledge has allowed the formulation and testing of hypotheses in an increasingly detailed way: the uplift of the Andes and its influence on the evolution and reconfiguration of the drainage system; and climatic oscillations due to glacial cycles during the Quaternary (Baker et al. 2014). Today it is clear that these histories are neither spatially or temporally independent, and despite many uncertainties, the association between biological and geological data has decisively helped to elucidate the relationship between environmental history and the origin of diversity in Amazonia (Baker et al. 2014). It is also clear that forest environments associated with different degrees of flooding (Figure 1) have had very different histories, as they respond differently to drainage evolution and paleoclimatic change (Harvey et al. 2017, Thom et al. 2018, Ribas et al. 2018).

The Quaternary climatic oscillations (2.6 Ma to the present) are traditionally associated with forest refuges, as proposed by Haffer (1969). Drainage evolution, on the other hand, is generally associated with Miocene events (23 to $5 \mathrm{Ma}$ ), when the main phase of Andean uplift would have occurred (Hoorn et al. 2010, but see discussion in Baker et al. 2014). Due to this apparent temporal segregation of geological events, for a long time tests of diversification hypotheses have been based on dating the divergences to determine their causes: diversification in the Pleistocene would be associated with refuges while diversification in the Miocene would be associated to drainage evolution (Rull 2014). Meanwhile, the lack of simple and straightforward congruence among the different groups led to an alternative interpretation of a weak association between environmental history and biotic diversification in Amazonia (Smith et al. 2014).

However, the analytical approach needs to become more sophisticated (Papadopoulou and Knowles 2016). The accumulation of knowledge about the evolution of the Amazonian landscapes shows that different forces, initially associated with different hypotheses (eg. refuges, rivers), often considered as alternative, acted together spatially and temporally (Baker et al. 2014, Weir et al. 2015). In addition, environmental history has increasingly been shown to be complex. The climate of Amazonia did not vary uniformly during glacial cycles (Cheng et al. 2013, Wang et al. 2017), 
and the response of forest and open formations to these oscillations is still much debated and poorly understood (Mayle et al. 2004, Cowling et al. 2001, Anhuf et al. 2006).

Most debates concerning the recent evolution of the Amazonian drainage have focused on the establishment of the transcontinental system, which has been suggested as the main driver of the onset of the Terra Firme formation in western Amazonian lowlands. A mid-Miocene age (9.4 to $9.0 \mathrm{Ma}$ ) for the onset of the trans-Amazon drainage has been linked to the period of decreasing deposition of the Solimões Formation (Solimões Fm) in western Amazonia and increased sedimentation rates at the Amazon Fan (Hoorn et al. 2010). However, the age of the upper Solimões Fm is still debated, and paleontological data suggest a late Miocene to early Pliocene age for the formation of the modern Amazon River (Latrubesse et al. 2010). In contrast, evidences from different proxies for defining the ages of the sedimentary deposits that overlap different areas of western and central Amazonia suggest younger ages for the establishment of the modern fluvial system, as Plio-Pleistocene (Nogueira et al. 2013) and mid to late Pleistocene (Rossetti et al. 2015). Recently, an alternative paleogeographic scenario suggests that the development of the modern drainage took place in steps since the late Oligocene-early Miocene until the Quaternary and not as a single event (van Soelen et al. 2017, Pupim et al. 2019). The recent development of research in sedimentology and paleoclimatology has provided increasingly detailed data, making possible a more specific association between landscape evolution and the spatial distribution of genetic diversity in the organisms that currently occupy the different environments (Figure 2) (Baker et al. 2014). Parallel to the advances in these areas of knowledge, significant advances in analytical methods in molecular phylogeny and phylogeography were also observed, making it possible to test these more detailed and complex scenarios (Toews et al. 2016).
Molecular phylogenetic and phylogeographic studies of groups for which taxonomy and sampling in Amazonia are better developed, as in birds and primates but also some groups of insects, frogs and small mammals, have repeatedly indicated that most current Amazonian species originated during the Pliocene and Pleistocene (Ribas et al. 2012, Boubli et al. 2015, Rull 2011, Garzón-Orduña et al. 2014, Smith et al. 2014, Pavan et al. 2016, Ribas et al. 2018) a timing that is partially consistent with a role for climate oscillations due to glacial cycles. However, most species are older than the LGM, meaning that the last glacial cycle has not disrupted pre-existing patterns of diversity and distribution (Ribas et al. 2012). Also, Quaternary drier climates seem to have been less pronounced in western Amazonia (Cheng et al. 2013, Wang et al. 2017), where the highest species diversity is concentrated today. This evidence suggests that a more thorough understanding of landscape evolution, not strictly focused on the effect of precipitation changes on vegetation as postulated by the Refugia hypothesis, is needed to decipher its relationship to biotic diversification. However, the uncertainty about the timing of the evolution of the drainage system and its associated environments has precluded such integration.

\section{INTEGRATING HISTORY AND ECOLOGY}

Since the proposal of phylogeography by Avise et al. (1987) the idea was to seek an integration of intraand inter-specific genetic variability to understand the continuum of variation from polymorphism (population genetics) to divergence (phylogeny). This search involves an integration between historical data and data on the environments in which individuals occur today (Figure 2).

The importance of historical and ecological factors for community structuring is a consensus in the literature. However, few studies have determined the relative contribution of each of these factors. 


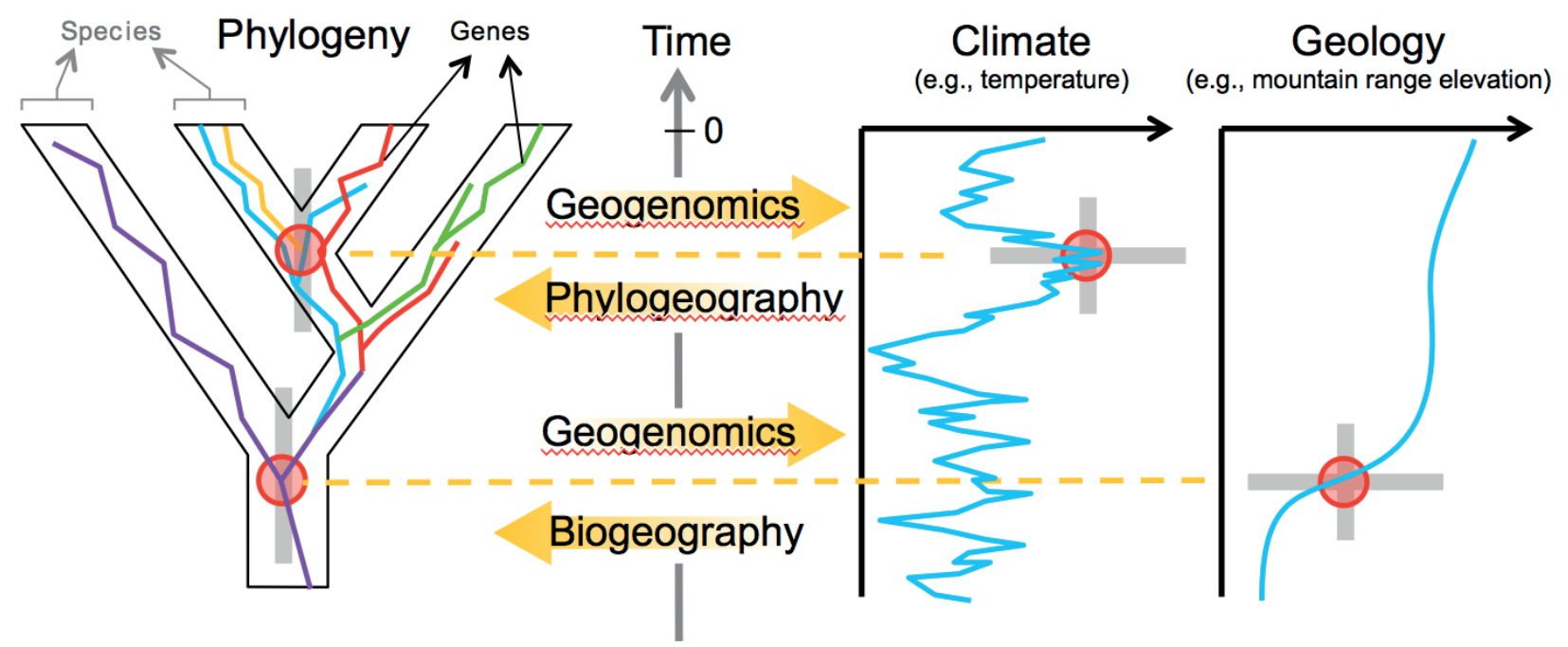

Figure 2 - In the phylogenetic tree (left), black 'tubes' represent species (i.e. the species tree), whose individuals are characterized by genes with different mutational histories (color lines within tubes; i.e. the gene tree). On the right, a climatic time series and temporal variation of a geologic feature are represented. Red circles and orange dashed lines highlight the correspondence between evolutionary and climatic/geologic events; gray bars represent confidence intervals for the timing of divergence (left) or the geologic/climatic events (right). Figure from Baker et al. (2014).

This is largely due to the lack of information on ecology and on the detailed patterns of occurrence of species (Hortal et al. 2015). Although many groups of organisms appear to be widely distributed in tropical regions, only recently studies have begun to document the detailed pattern of variation in species occurrence (Costa and Magnusson 2010) and the genetic structure within species, that often correspond to several independent evolutionary units (Aleixo 2004, Antonelli et al. 2010, Ribas and Miyaki 2004, Ribas et al. 2005, 2006, 2007, 2009, 2012, Schultz et al. 2016).

A good understanding of the patterns of occurrence and abundance of species in association with detailed information on the patterns of niches and habitats occupation within each community are critical for the testing of ecological and biogeographic hypotheses. Only through an integrated and multidisciplinary approach can we understand the great diversity of factors associated with the origin and maintenance of the most diverse biome on the planet, the Amazon Forest. This understanding is very important not only from a theoretical point of view, but also to guide actions to conserve this megadiversity that is under increasing risk of destruction. Understanding the biogeographic patterns allows us to better estimate the impact of deforestation in certain regions of the Amazon, because it is possible to know which regions harbor greater diversity, or unique and endemic lineages, while understanding intrapopulational processes that shaped current diversity patterns helps us predict the consequences of fragmentation, future climate change and habitat loss.

\section{IMPACT OF LARGE DAMS ON THE AVIFAUNA ASSOCIATED TO FLOODED ENVIRONMENTS}

Despite being the world's most species-diverse biome (Pimm et al. 2014, Jenkins et al. 2013), Amazonia includes a below-average proportion of threatened species (Vale et al. 2008). While this may seem an indication of resilience and robustness, caution is required for two main reasons: Amazonia currently experiences the highest absolute rate of forest loss (Soares-Filho et al. 2006) and the 
number of species classified as threatened is likely to be an artifact of poor taxonomic knowledge (Bates and Demos 2001, Whitney and Cohn-Haft 2014). This is especially important for the biota associated with flooded environments, as it is particularly understudied (Cohn-Haft et al. 2007) and the current model of hydropower development will focus the impact of the dam's lakes on these environments by adopting the run-of the river model (Latrubesse et al. 2017).

Surveys and meta-analyses of diversity patterns are dependent upon basic information of species delimitation. Phylogeographic studies of Amazonian vertebrates have often revealed more distinct evolutionary lineages than previously recognized by traditional taxonomy (e.g. Smith et al. 2014), and often the relationships among these lineages do not correspond to former generic or species limits (Ribas et al. 2005, 2006, 2007, 2012). This 'taxonomic shortfall' prevents meta-analyses based on current taxonomy from achieving an accurate representation of diversity patterns (Figure 1 ), and consequently from inferring processes and defining conservation strategies (Bates and Demos 2001, Hortal et al. 2015).

Comparatively, birds are among the taxonomically better known groups of Amazonian organisms, even though many new species continue to be discovered (Whitney and CohnHaft 2014). In addition, although the large-scale biogeography of Amazonian birds is comparatively well documented, there are multiple examples in which fine-grained patterns of diversity are being discovered that reflect landscape history (e.g. Ribas et al. 2012, d'Horta et al. 2013, Thom and Aleixo 2015). This is particularly true for upland forest birds, for which multiple taxonomic reviews have been published (Bates and Demos 2001, Ribas et al. 2012, Fernandes et al. 2013). In stark contrast, the avifauna associated with flooded environments is still poorly known, with few systematic revisions and a prevailing impression of uniformity of the intraspecific diversity (Aleixo 2006, Cadena et al. 2011). Contrary to these first impressions, recent detailed descriptions of phenotypic variation and genetic diversity within flood-plain forest birds have documented that there is considerable unrecognized intraspecific diversity, and that when this is accounted for, common spatial patterns of distribution are revealed (Cohn Haft et al. 2007, Canton 2014, Choueri et al. 2017, Harvey et al. 2017, Thom et al. 2018). This evidence suggests that planning for hydropower generation in Amazonia is moving forward with poor knowledge about the species diversity that will be impacted (Figure 3).

Flooded habitat species are dependent upon environments created by rivers and the flooding cycle and their evolution are historically linked to the Amazonian drainage system (Moraes et al. 2016). Current reconstructions propose that western Amazonia was covered by a system of wetlands during a large period in the last $10 \mathrm{Ma}$, and that the current transcontinental drainage system is relatively recent (Latrubesse et al. 2010, Nogueira et al. 2013, Rossetti et al. 2015). This dynamic history may have had strong influence over the recent evolution of species adapted to flooded environments, which brought about changes in their distributions as well as possible disconnections between eastern and western populations. Such a scenario is suggested by phenotypic variation in several species of birds (Cohn-Haft et al. 2007) and has been confirmed through genomic analysis of parrots and passeriforms (Canton 2014, Thom et al. 2018). This dynamic history may also have resulted in distinct degrees of intraspecific genetic diversity, depending on how species have responded to the physical changes to their habitats. Quantifying this diversity is important for conservation planning (Figure 3), as populations with very low genetic diversity may be less capable of responding to environmental impacts and thus are more susceptible to population fragmentation 


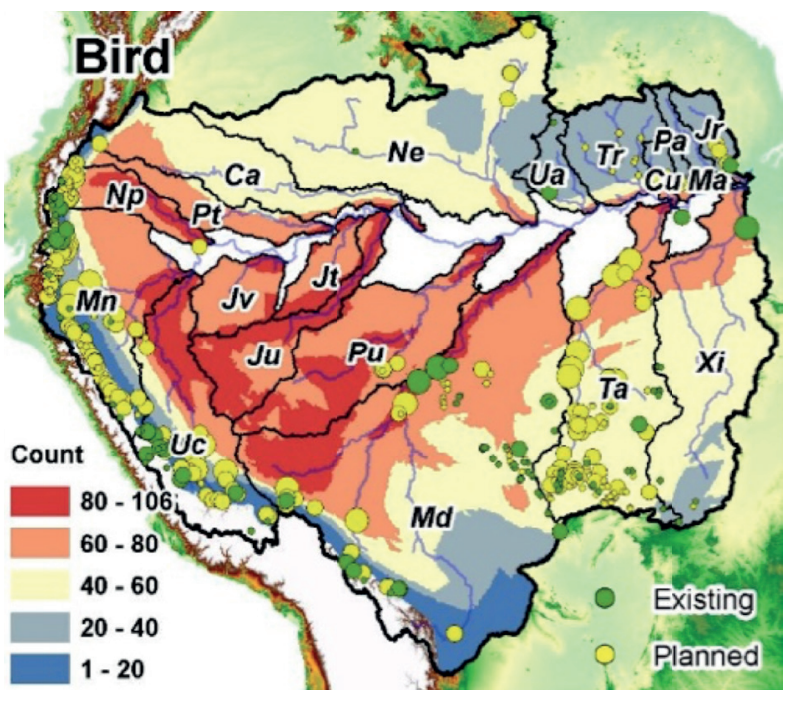

Figure 3 - Flooded habitat birds (non-aquatic) species richness patterns of Amazonian river basins. Color scale from blue (low) to red (high) represent the number of species. Number of species based on overlapping distributions of each single species. Green and yellow circles are location of dams. Figure from Latrubesse et al. (2017). Amazon's 19 sub-basins are labeled with abbreviations: Andean-foreland Rivers: Marañon $(M n)$, Ucayali $(U c)$, Napo $(N p)$, Putumayo $(P t)$, Caqueta $(\mathrm{Ca})$; Cratonic rivers: Jari $(\mathrm{Jr})$, Paru $(\mathrm{Pa})$, Curuapenema $(C u)$, Maricuru (Ma), Tapajós (Ta), Xingu $(X i)$, Trombetas $(T r)$, Negro $(N e)$, Uatumã $(U a)$, Mixed terrain: Madeira $(M d)$; Lowland rivers: Jurua $(J u)$, Purus $(P u)$, Jutai $(J t)$, Javari $(J v)$.

and extinction (Spielman, 2004). A better understanding of systematics and biogeography of Amazonian biota will be critical for any planning process involving developmental activities.

\section{MOLECULAR DATA IN BIOGEOGRAPHY}

The use of molecular data has brought two important novelties to biogeographic studies: the possibility of making temporal inferences and the possibility of studying the recent history of populations (Carstens and Richards 2007). Although the molecular data initially led to biogeographic studies focused on individual groups, diminishing the importance of the fundamentally comparative nature of classical biogeography, the evolution of data collection and analysis methodologies is allowing for a return to a comparative framework (Papadopoulou and Knowles 2016).
In the last decade, large-scale molecular data collection has become much easier and faster (McCormack et al. 2012). Next-generation sequencing techniques (NGS) have recently introduced the possibility of sequencing many regions of the genome in parallel, allowing a much faster and cheaper sequencing of thousands of loci. The selection of markers in this new era of genomic studies is based on how to reduce the genome for sequencing, i.e. select the set of thousands of markers to be studied. This can be done through traditional amplification of known regions and subsequent sequencing in parallel; digestion of the genome with restriction enzymes and size selection of fragments to be sequenced; or by using probes that bind to specific regions of the genome leading to sequencing of the adjacent regions (Harvey et al. 2016). The aim is to sequence a large number of homologous regions of appropriate size for phylogeographic analyzes. Despite some standing methodological difficulties, including how to combine fragments to perform each analysis and issues related to missing data (McCormack et al. 2012), several studies have successfully used NGS data to test biogeographic hypotheses using probes that bind to ultra-conserved genome regions (Smith et al. 2014) or SNPs obtained by DNA fragmentation and subsequent sequencing (GBS, ddRAD) (Harvey and Brumfield 2015, Weir et al. 2015, see review in Toews et al. 2016) (Figure 2).

This abundance of genetic information, coupled with the growing knowledge of Earth's history, especially the evolution of the Amazonian landscape, presents fascinating possibilities for understanding the mechanisms that govern the origin and maintenance of diversity patterns in one of the most diverse regions of the world (Figure 2). For this, we will increasingly need more intense and coordinated interactions between researchers studying biotic diversification and the evolution of landscapes (Baker et al. 2014, Cheng et al. 2013, Hoorn et al. 2010, Pupim et al. 2019). From the 
interaction between these two fields of knowledge that are in full development, an increasingly detailed understanding of the historical mechanisms related to the origin of the species will surely arise.

\section{ACKNOWLEDGMENTS}

We thank our students, who have generated, analyzed and discussed data, both stimulating and instigating us. These ideas have been developed with support from the grants: "Dimensions USBiota-São Paulo: Assembly and evolution of the Amazon biota and its environment: an integrated approach", co-funded by the US National Science Foundation (NSF DEB 1241066), National Aeronautics and Space Administration (NASA), and the São Paulo Research Foundation (FAPESP, grant \#2012/50260-6); PEER/USAID (AIDOAA-A-11-00012); and NSF FESD (EAR1338694). CCR is supported by a CNPq research fellowship (308927/2016-8). Support has also been provided by CNPq, CAPES and FAPEAM in the form of student fellowships and research grants. We thank the Brazilian Academy of Sciences, especially Professors Vivaldo Moura Neto and Adalberto Luis Val, for the invitation to participate in the Brazil-France Bilateral Symposium on Biodiversity held at the Federal University of Amazonas in June 2018.

\section{AUTHOR CONTRIBUTIONS}

Both authors have discussed and gathered data on these topics for many years. CCR wrote the text, AA revised and complemented it.

\section{REFERENCES}

ALEIXO A. 2004. Historical diversification of a terra-firme forest bird superspecies: A phylogeographic perspective on the role of different hypothesis of Amazonian diversification. Evolution 58: 1303-1317.

ALEIXO A. 2006. Historical diversification of floodplain forest specialist species in the Amazon: a case study with two species of the avian genus Xiphorhynchus (Aves: Dendrocolaptidae). Biol J Linn Soc 89(2): 383-395.

ANHUF D ET AL. 2006. Paleo-environmental change in Amazonian and African rainforest during the LGM. Palaeogeogr Palaeoclimatol Palaeoecol 239: 510-527.

ANTONELLI A, QUIJADA-MASCAREÑAS JA, CRAWFORD AJ, BATES JM, VELAZCO PM AND WUSTER CE. 2010. Molecular studies and phylogeography of Amazonian tetrapods and theis relation to geological and climatic models. In: Hoorn $\mathrm{C}$ and Wesselingh FP (Eds), Amazonia: landscape and species evolution, Oxford, UK: Wiley-Blackwell, p. 386-404.

AVISE JC, ARNOLD J, BALL RM, BERMINGHAM E, LAMB T, NEIGEL JE, REEB CA AND SAUNDERS NC. 1987. Intraspecific phylogeography: The mitochondrial DNA bridge between population genetics and systematics. Annu Rev Ecol Syst 18: 489-522.

BAKER PA, FRITZ SC, DICK CW, ECKERT AJ, HORTON BK, MANZONI S, RIBAS CC, GARZIONE CN AND BATTISTI DS. 2014. The emerging field of geogenomics: Constraining geological problems with genetic data. EarthSci Rev 135: 38-47.

BATES JM AND DEMOS TC. 2001. Do we need to devalue Amazonia and other large tropical forests? Divers Distrib 7: 249-255.

BOUBLI JP, RIBAS C, LYNCH ALFARO JW, ALFARO ME, DA SILVA MN, PINHO GM AND FARIAS IP. 2015. Spatial and temporal patterns of diversification on the Amazon: A test of the riverine hypothesis for all diurnal primates of Rio Negro and Rio Branco in Brazil. Mol Phylogenet Evol 82 Pt B: 400-412.

CADENA CD, GUTIÉRREZ-PINTO N, DÁVILA N AND CHESSER RT. 2011. No population genetic structure in a widespread aquatic songbird from the Neotropics. Mol Phylogenet Evol 58: 540-545.

CANTON R. 2014. Análise da variação fenotípica e genotípica do complexo Brotogeris sanctithomae (Aves: Psittaciformes). Mestrado, INPA. (Unpublished).

CARSTENS BC AND RICHARDS CL. 2007. Integrating coalescent and ecological niche modeling in comparative phylogeography. Evolution 61: 1439-1454.

CHENG H, SINHA A, CRUZ FW, WANG X, EDWARDS RL, D'HORTA FM, RIBAS CC, VUILLE M, STOTT LD AND AULER AS. 2013. Climate change patterns in Amazonia and biodiversity. Nat Commun 4: 1411.

CHOUERI EL, GUBILI C, BORGES SH, THOM G, SAWAKUCHI AO, SOARES EAA AND RIBAS CC. 2017. Phylogeography and population dynamics of Antibirds (Thamnophilidae) from Amazonian fluvial islands. J Biogeogr 44: 2284-2294.

COHN-HAFT M, NAKA L AND FERNANDES A. 2007. Padrões de distribuição da avifauna da várzea dos rios Solimões e Amazonas. Conservação da várzea: 
identificação e caracterização de regiões biogeográficas Manaus, Ibama, ProVárzea, 356 p: 287-323.

COSTA FRC AND MAGNUSSON WE. 2010. The need for large-scale, integrated studies of biodiversity: the experience of the Program for Biodiversity Research in Brazilian Amazonia. Nat Conservação 8: 3-12.

COWLING SA, MASLIN MA AND SYKES MT. 2001. Paleovegetation Simulations of Lowland Amazonia and Implications for Neotropical Allopatry and Speciation. Quaternary Res 55: 140-149.

D'HORTA FM, CUERVO AM, RIBAS CC, BRUMFIELD RT AND MIYAKI CY. 2013. Phylogeny and comparative phylogeography of Sclerurus (Aves: Furnariidae) reveal constant and cryptic diversification in an old radiation of rain forest understorey specialists. J Biogeogr 40: 37-49.

FERNANDES AM, GONZALEZ J, WINK M AND ALEIXO A. 2013. Multilocus phylogeography of the Wedge-billed Woodcreeper Glyphorynchus spirurus (Aves, Furnariidae) in lowland Amazonia: widespread cryptic diversity and paraphyly reveal a complex diversification pattern. Mol Phylogenet Evol 66: 270-282.

GARZÓN-ORDUÑA IJ, BENETTI-LONGHINI JE, BROWER AVZ AND RIDDLE B. 2014. Timing the diversification of the Amazonian biota: butterfly divergences are consistent with Pleistocene refugia. J Biogeogr 41: 1631-1638.

HAFFER J. 1969. Speciation in amazonian forest birds. Science 165: 131-137.

HAFFER J. 2008. Hypotheses to explain the origin of species in Amazonia. Braz J Biol 68: 917-947.

HARVEY MG, ALEIXO A, RIBAS C AND BRUMFIELD RT. 2017. Habitat association predicts genetic diversity and population divergence in Amazonian birds. Am Nat 190: 631-648.

HARVEY MG AND BRUMFIELD RT. 2015. Genomic variation in a widespread Neotropical bird (Xenops minutus) reveals divergence, population expansion, and gene flow. Mol Phylogenet Evol 83: 305-316.

HARVEY MG, SMITH BT, GLENN TC, FAIRCLOTH BC AND BRUMFIELD RT. 2016. Sequence Capture versus Restriction Site Associated DNA Sequencing for Shallow Systematics. Syst Biol 65: 910-924.

HOORN C ET AL. 2010. Amazonia through time: Andean uplift, climate change, landscape evolution, and biodiversity. Science 330: 927-931.

HORTAL J, BELLO F, DINIZ-FILHO JAF, LEWINSOHN TM, LOBO JM AND LADLE RJ. 2015. Seven shortfalls that beset large-scale knowledge of biodiversity. Annu Rev Ecol Evol Syst 46: 523-549.

JENKINS CN, PIMM SL AND JOPPA LN. 2013. Global patterns of terrestrial vertebrate diversity and conservation. PNAS 110: E2602-2610.
LATRUBESSE EM, COZZUOL M, CAMINHA SS, RIGSBY C, ABSY M AND JARAMILlO C. 2010. The Late Miocene paleogeography of the Amazon Basin and the evolution of the Amazon River system. Earth Sci Rev 99: 99-124

LATRUBESSE EM ET AL. 2017. Damming the rivers of the Amazon basin. Nature 546: 363-369.

LEITE RN AND ROGERS DS. 2013. Revisiting Amazonian phylogeography: insights into diversification hypotheses and novel perspectives. Org Divers Evol 13: 639-664.

MAYLE FE, BEERLING DJ, GOSLING WD AND BUSH MB. 2004. Responses of Amazonian ecosystems to climatic and atmospheric carbon dioxide changes since the last glacial maximum. Philos Trans R Soc Lond B Biol Sci 359: 499-514.

MCCORMACK JE, HIRD SM, ZELLMER AJ, CARSTENS BC AND BRUMFIELD RT. 2012. Applications of next-generation sequencing to phylogeography and phylogenetics. Mol Phylogenet Evol 66: 526-538.

MORAES LJCL, PAVAN D, BARROS MC AND RIBAS CC. 2016. The combined influence of riverine barriers and flooding gradients on biogeographical patterns for amphibian and squamates in south-eastern Amazonia. J Biogeogr 43: 2113-2124.

NAKA LN AND BRUMFIELD RT. 2018. The dual role of Amazonian rivers in the generation and maintenance of avian diversity. Science Advances 4: eaar8575.

NOGUEIRA ACR, SILVEIRA R AND GUIMARÃES JTF. 2013. Neogene-Quaternary sedimentary and paleovegetation history of the eastern Solimões Basin, central Amazon region. J South Am Earth Sci 46: 89-99.

PAPADOPOULOU A AND KNOWLES LL. 2016. Toward a paradigm shift in comparative phylogeography driven by trait-based hypotheses. PNAS 113: 8018-8024.

PAVAN SE, JANSA SAAND VOSS RS. 2016. Spatiotemporal diversification of a low-vagility Neotropical vertebrate clade (short-tailed opossums, Didelphidae: Monodelphis). J Biogeogr 43: 1299-1309.

PIMM SL ET AL. 2014. The biodiversity of species and their rates of extinction, distribution, and protection. Science 344: 1246752

PUPIM FN ET AL. 2019. Chronology of Terra Firme formation in Amazonian lowlands reveals a dynamic Quaternary landscape. Quat Sci Rev 210: 154-163.

RIBAS CC, ALEIXO A, GUBILI C, D'HORTA FM, BRUMFIELD RT AND CRACRAFT J. 2018. Biogeography and diversification of Rhegmatorhina (Aves: Thamnophilidae): Implications for the evolution of Amazonian landscapes during the Quaternary. J Biogeogr 45: 917-928.

RIBAS CC, ALEIXO A, NOGUEIRA AC, MIYAKI CY AND CRACRAFT J. 2012. A palaeobiogeographic model for 
biotic diversification within Amazonia over the past three million years. Proc Biol Sci 279: 681-689.

RIBAS CC, GABAN-LIMA R, MIYAKI CY AND CRACRAFT J. 2005. Historical biogeography and diversification within the Neotropical parrot genus Pionopsitta (Aves: Psittacidae). J Biogeogr 32: 1409-1427.

RIBAS CC, JOSEPH L AND MIYAKI CY. 2006. Molecular systematics and patterns of diversification in Pyrrhura (Psittacidae), with special reference to the picta-leucotis complex. Auk 123: 660-680.

RIBAS CC AND MIYAKI CY. 2004. Molecular systematics in Aratinga parakeets: species limits and historical biogeography in the 'solstitialis' group, and the systematic position of Nandayus nenday. Mol Phylogenet Evol 30: 663-675.

RIBAS CC, MIYAKI CY AND CRACRAFT J. 2009. Phylogenetic relationships, diversification and biogeography in Neotropical Brotogeris parakeets. J Biogeogr 36: 1712-1729.

RIBAS CC, TAVARES ES, YOSHIHARA C AND MIYAKI CY. 2007. Phylogeny and biogeography of Yellow-headed and Blue-fronted Parrots (Amazona ochrocephala and Amazona aestiva) with special reference to the South American taxa. Ibis 149: 564-574.

ROSSETTI DF ET AL. 2015. Mid-Late Pleistocene OSL chronology in western Amazonia and implications for the transcontinental Amazon pathway. Sediment Geol 330: $1-15$.

RULL V. 2011. Neotropical biodiversity: timing and potential drivers. Trends Ecol Evol 26: 508-513.

RULL V. 2014. Pleistocene speciation is not refuge speciation. J Biogeogr 42: 602-604.

SCHULTZ ED, BURNEY CW, BRUMFIELD RT, POLO EM, CRACRAFT J AND RIBAS CC. 2017. Systematics and biogeography of the Automolus infuscatus complex (Aves; Furnariidae): Cryptic diversity reveals western Amazonia as the origin of a transcontinental radiation. Mol Phylogenet Evol 107: 503-515.

SMITH BT ET AL. 2014. The drivers of tropical speciation. Nature 515: 406-409.

SOARES-FILHO BS ET AL. 2006. Modeling conservation in the Amazon basin. Nature 440: 520-523.
SPIELMAN D, BROOK BW AND FRANHAM R. 2004. Most species are not driven to extinction before genetic factors impact them. PNAS 101:15261-15264.

THOM G AND ALEIXO A. 2015. Cryptic speciation in the white-shouldered antshrike (Thamnophilus aethiops, Aves - Thamnophilidae): the tale of a transcontinental radiation across rivers in lowland Amazonia and the northeastern Atlantic Forest. Mol Phylogenet Evol 82 Pt A: 95-110.

THOM G, AMARAL FR, HICKERSON MJ, ALEIXO A, ARAUJO-SILVA LE, RIBAS C, CHOUERI E AND MIYAKI CY. 2018. Phenotypic and genetic structure support gene flow generating gene tree discordances in an Amazonian floodplain endemic species. Syst Biol 67: 700-718.

TOEWS DPL ET AL. 2016. Genomic approaches to understanding population divergence and speciation in birds. Auk 133: 13-30.

VALE MM, COHN-HAFT M, BERGEN S AND PIMM SL. 2008. Effects of future infrastructure development on threat status and occurrence of Amazonian birds. Conserv Biol 22: 1006-1015.

VAN SOELEN EE, KIM J-H, SANTOS RV, DANTAS EL, ALMEIDA FV, PIRES JP, RODDAZ M AND DAMSTÉ JSS. 2017. A 30 Ma history of the Amazon River inferred from terrigenous sediments and organic matter on the Ceará Rise. Earth Planet Sci Lett 474: 40-48.

WALLACE AR. 1852. On the monkeys of the Amazon. Alfred Russel Wallace Writings 3.

WANG X, EDWARDS RL, AULER AS, CHENG H, KONG $\mathrm{X}$, WANG Y, CRUZ FW, DORALE JA AND CHIANG H-W. 2017. Hydroclimate changes across the Amazon lowlands over the past 45,000 years. Nature 541: 204-207.

WEIR JT, FACCIO MS, PULIDO-SANTACRUZ P, BARRERA-GUZMAN AO AND ALEIXO A. 2015. Hybridization in headwater regions, and the role of rivers as drivers of speciation in Amazonian birds. Evolution 69: 1823-1834.

WHITNEY BM AND COHN-HAFT M. 2014. Fifteen new species of Amazonian birds. In: Del Hoyo J, Elliot A, Sargatal J and Christie DA (Eds), Handbook of the birds of the world. Special Volume: New species and global index, Barcelona, Spain, Lynx Ediciones, v. 17, p. 225-239. 